\title{
It's Cool Inside: Advertising Air Conditioning to Postwar Suburbia
}

\section{Andrea Vesentini}

Everything worth saying about the American way of life I could put in thirty pages. Topographically the country is magnificent - and terrifying. Why terrifying? Because nowhere else in the world is the divorce between man and nature so complete. ${ }^{1}$

Henry Miller, The Air-Conditioned Nightmare, 1945

The amenities of modern life, such as panel-heating or air conditioning, humidifying and dehumidifying, have fostered the belief that we have "conquered" the inconveniences of our climate. We have ice-skating rinks in summer, and warm outdoor swimming pools in winter. ... Still, nobody could say that we have come to terms with the outdoors. We merely retreated after a spiritless campaign to, what defeated generals referred to as, pre-arranged positions. ${ }^{2}$

Bernard Rudofsky, Behind the Picture Window, 1955

In July 1945, as the world conflict was nearing its end, Life readers were given a preview of postwar domestic bliss. What they were shown, however, might not look exactly appealing at first glance: an image of a smoke-filled dining room [Figure 1]. Had one of the new electric gadgets short-circuited? Or 


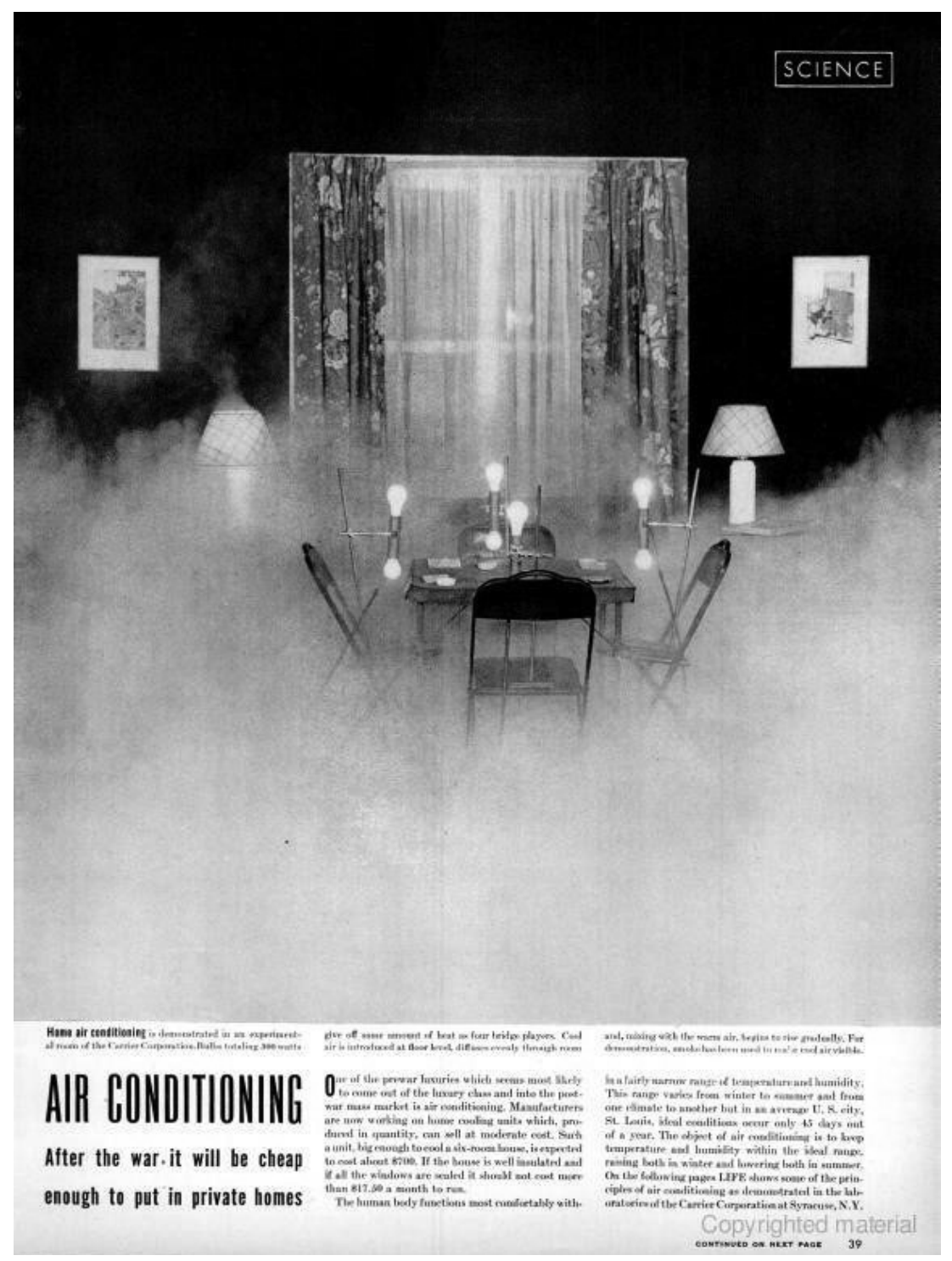

Figure 1: "Air conditioning: After the war it will be cheap enough to put in private homes." Life, July 16, 1945, 39.

had perhaps fallout found a way into the suburban house? No need to panic: the bomb was just around the corner but still far from the mind of most Americans. Life was just prophesying the upcoming success of the new wonder in modern living: air conditioning. How to portray the new technology was, however, quite a thorny issue for a magazine whose success came from visual rather than 
written commentaries. The awkward solution came with Carrier Corporation adding smoke to the cooling device in one of its experimental rooms to make the refrigerated air visible in the photograph. ${ }^{3}$

Ingenious as it was, could the same trick be used for advertising? Was not the picture of a gas chamber rather counterproductive, given the recent war events? Unlike refrigerators and other household appliances, the trouble with air conditioning was the invisibility of its benefits. The image of a fuming chicken perfectly showed the miracle of an electric oven, and a fresh cut of meat was enough to prove the comforts of a fridge, but how could the cool experience be made visible? Refrigeration was no longer just about storing food but also about living well. In a marketing industry that was increasingly dominated by images, there had to be one for coolness. ${ }^{4}$

This article explores how advertisers in the postwar decades-roughly from 1945 to the end of the 1960s - devised visual strategies to convey the benefits of air conditioning and link them to a suburban lifestyle. The very word of choice to describe the pleasures of climate control, "cool" as a milder coldness a step closer to warmth but miles away from heat, curbed extremes in a fashion typical of suburbia, a middle landscape between city and country where one could enjoy the benefits of both in moderation. In so doing, these ads articulated specific social dynamics that associated climatic comfort with social status by providing a hierarchical representation of interiors and exteriors, contrasting the desirability of the former with the discomforts of the latter. These metaphors eventually went as far as suggesting that air conditioning would ultimately recreate a better rendition of the outdoors within the home. This latest stretch of the imagination proved necessary to counteract the fear that the claustrophobic properties of the technology, whose end goal was in fact the interior's climatic self-sufficiency from the exterior, would run against the assumption that suburbia afforded the green pastures and open air that the city lacked.

The extensive historiography on postwar suburbia has seldom addressed the role of air conditioning in constructing and disseminating the ideal of suburban domesticity in the booming years of suburbanization, spanning from the end of the war until the mid-1960s. Histories of air conditioning have mostly chronicled its rise and spread into the private domestic market, but little has been written on how its representation in popular culture increased the appeal of suburban living among the middle class. Another Life photo-essay, published one year after the smoky room, found that what most Americans yearned for as a long-deserved reward for the mass effort of the conflict was a "a rosy future of rich cars and wondrous homes," "a brave new postwar world that would be full of air-conditioned peace and electronically controlled plenty." Climate control was thus a constitutive part of this image of suburban idyll. ${ }^{5}$

Air conditioning crossed paths with advertising when it spread to the suburban household. As historian Lizabeth Cohen has noted, suburbs were "the distinctive residential landscape of the Consumer's Republic, that commitment to rebuild the American economy and society after World War II around the 
mass consumer market." They were the place where most new housing was being built and thus a veritable gold mine for household appliance manufacturers. For the climate-control industry, they also offered a landscape where people spent an increasingly larger part of their lives in a set of innumerable interiors, from cars to houses and enclosed malls, for all of which air conditioning would prove highly beneficial if not necessary. How could anyone survive in the new all-indoor shopping centers without it? How could the longer hours spent behind the wheel by commuters or in the house by their stay-at-home wives be made more tolerable? ${ }^{6}$

As air-conditioning producers provided a technological answer to such questions, the goal for Madison Avenue was to show how climate control made this new spatial setup alluring. As Susan Strasser has written, the role of advertisers and market researchers is to foster

new needs and new habits not by creating them out of whole cloth but by linking the rapid appearance of new products with the rapid changes in all areas of social and cultural life. Buying behavior depended on new behavior at home and in the workplace, which manufacturers and their advertising agents consciously promoted in their emphasis on new product categories. ${ }^{7}$

Seen under this light, the unprecedented scale of suburbanization of the postwar era presented a perfect opportunity in terms of social and cultural change for the air-conditioning industry to expand into the residential market and beyond. This article will thus evidence how advertisers, by tying private interiors to images of comfort, leisure, and affluence, also encouraged their rise and helped suburban Americans, who were exponentially growing into the majority of the overall population, adjust to this new suburban geography, following Strasser's contention that advertising pinpoints but also promotes new behaviors. Despite McLuhan's claim that advertising aimed "to generate heat," this was a case when Madison Avenue had to cool down to invent the new graphics of refrigeration. ${ }^{8}$

\section{The Thin Glass between Heaven and Hell}

Climate control was far from being a novelty when Life published the smoke-filled room in 1945. In fact, Buffalo engineer Willis Carrier had patented his "Apparatus for Treating Air" as early as 1906. His Carrier Corporation would become the leading provider in the business during the interwar years, when the use of air conditioning was limited mostly to public buildings, such as department stores and movie theaters. To attract customers inside, these venues brandished catchphrases such as "it's cool inside," sometimes spelled "kool" to evoke both Alpine pleasures through the German-sounding spelling and the 
cigarette smoke that spiced up the freshness. A short time before the war broke out, the 1939 New York World's Fair presented its visitors with a rather cold preview of Levittown-style suburbia, the "Town of Tomorrow." The attraction predicted that the house of the future would be, by and large, climate controlled. In fact, most units in postwar subdivisions came with built-in central air conditioning to boost their appeal in the eyes of prospective buyers. A few steps away, Carrier's Igloo of Tomorrow sat next to the first tract of what would become the Long Island Expressway as the beacon of "the World's Fair Weather." However, the war brought the expansion into the house market to a standstill. ${ }^{9}$

After the war ended, the spread of air conditioning into private homes was easily integrated into the dream house narrative. On the cover of a 1944 Honeywell booklet on "Heating and Air-Conditioning the Postwar Home," the new technology was depicted as a superhero laying his hands over the roof [Figure 2]. It was like a new supernatural force, making weather no longer a prerogative of gods and nature. The interwar and wartime ads already articulated the relationship between natural and man-made climate in terms of conflict, implying that those who opposed air conditioning thwarted the course of human progress. The major air-conditioning companies tried to increase sales by claiming that artificial climate was superior to that found in nature, and movie theaters marketed themselves as a shelter from hot weather in summer. The trend was inscribed in the wider tendency of advertising at the time to show a "panicky reassertion of culture over nature," "an anxious impulse to extirpate all signs of biological life from one's immediate personal environment," as Jackson Lears has argued. ${ }^{10}$

Thermal discomfort was clearly one of such biological disadvantages. Since before the end of the war, all the new household appliances were in fact marketed with feisty futurism. If hot and cold were nature's imperfect idiosyncrasies, coolness was a perfect state that men could achieve only thanks to technology. Climate control exemplified the power of the modern house to master a force that was beyond human control. It fit perfectly within "the modern phase of the human struggle to make the interior independent from the exterior," as Srdjan Jovanovic Weiss has noted, a deliverance that took on special significance in the rising landscape of suburban interiors, resting on the long-standing rhetoric of individualism and self-reliance. ${ }^{11}$

The focus on place and experience rather than appliance was especially important to address the home owners' market. Air conditioners lay low in the phantasmagoria of glossy fridges and jam-packed cabinets sitting triumphantly in the middle of the house as totems of domestic modernization. Consumers often viewed the machinery as an unsightly bulge to be hidden behind curtains or disguised as furniture. What advertisers really needed to show were the benefits of air conditioning rather than the device that originated them. Some ads had characters float in a blue heaven of bliss: in a 1948 General Electric ad, a winged woman flew with her desk on cloud nine- "it's heavenly," she rejoiced. For the "Live Better ... Electrically" ad, the living room was nothing 


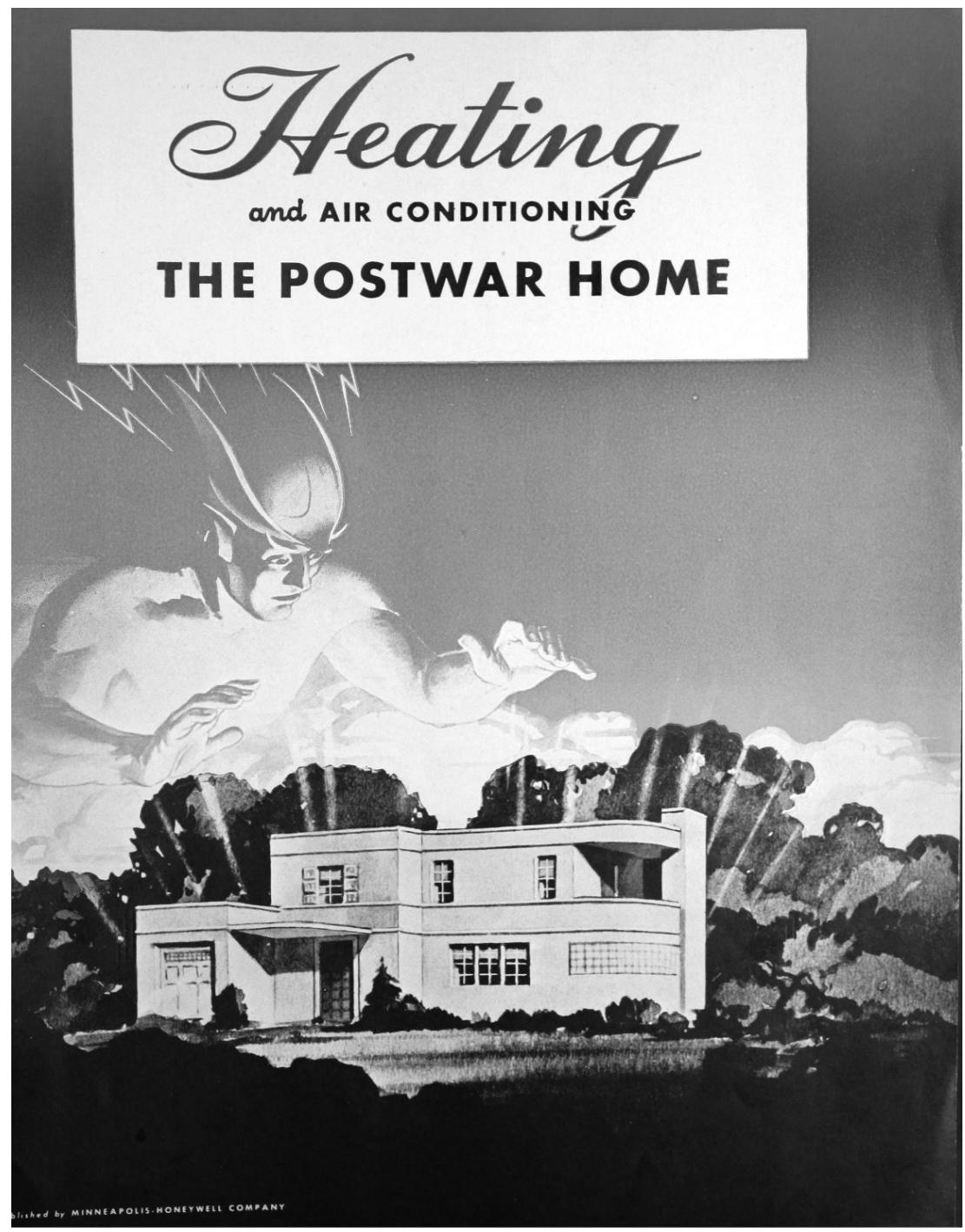

Figure 2: "Untitled cover illustration." Heating and Air Conditioning the Postwar Home (Minneapolis: Honeywell Company, 1944).

but a cloudless sky where a family cheerfully defied gravity as father returned from work. In a 1960 Frigidaire ad, a woman sat contentedly on an armchair suspended in bright blue air and surrounded by a stream of "stereo-cool" air. To one side, another picture showed an acid-green purgatory where a malfunctioning cooling unit did not cause the same elation, given the shadows that visually kept the woman with her feet firmly on the ground [Figure 3]. ${ }^{12}$ 


\section{NEW FRIGIDAIRE STERE0-COOLING Room Air Conditioners direct cool air...

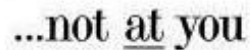 \\ ...but around you!}
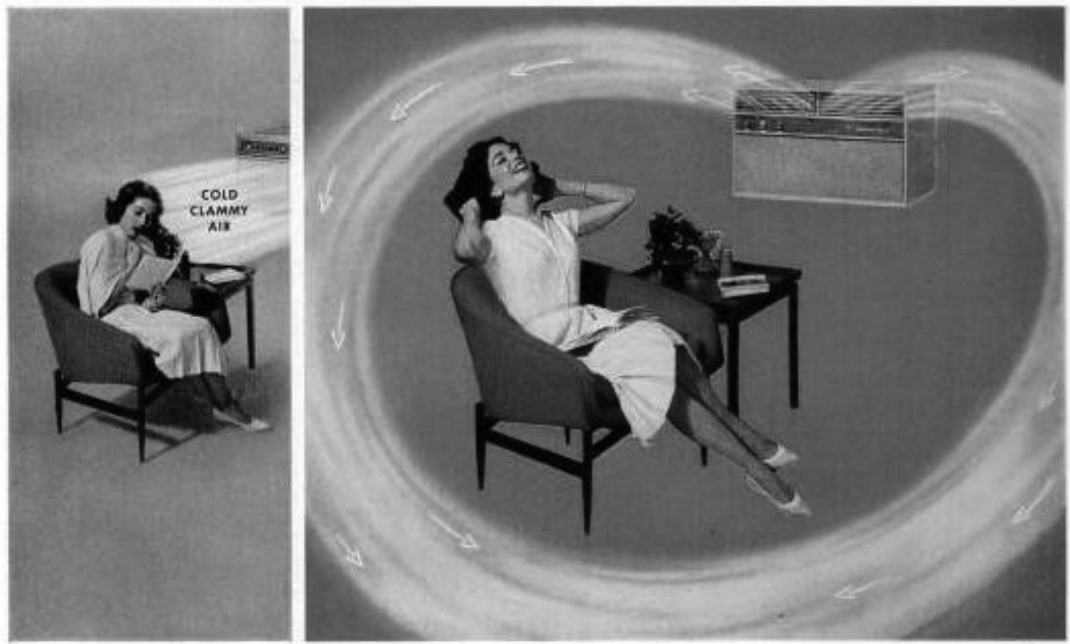

Fast cooling... Dry cooling... New quietness... all around you

Figure 3: "New Frigidaire Stereo Cooling." Frigidaire ad. Life, June 13, 1960, 124.

The drawback of most of these ads was the lack of a visual depiction of home. The miracle house was the heaven in which the cool family would fly, and the trick of turning it into an all-blue indefinite background was flawed by the same immaterialism that characterized the technology. Madison Avenue needed a clear-cut contrast between the downsides of a non-air-conditioned life and the modern house as the cool haven protecting its residents from the heatedup world outside. As Lisa Heschong contends in her study on the thermal properties of architecture, a way in which images can convey the temperature of a place is by associating it with either pleasure or displeasure. Such associations were offered on a silver plate by the binary spatial setup that was developing in suburbia, where introverted design was used to separate the domestic sphere from the street and public life. Starting from the late 1940s, suburban life was promoted through images of privacy, self-sufficiency, and secluded domesticity that kept outer intrusions at a distance. The home was envisioned as "a secure, private nest removed from the dangers of the outside world," as Elaine Tyler May has shown in her seminal study of the postwar family. ${ }^{13}$ 


\section{Now... Bouthy and Confort-a room air conditioner that FITS FLAT WITH THE WALL NO BULGE...IT'S A MITCHELL}

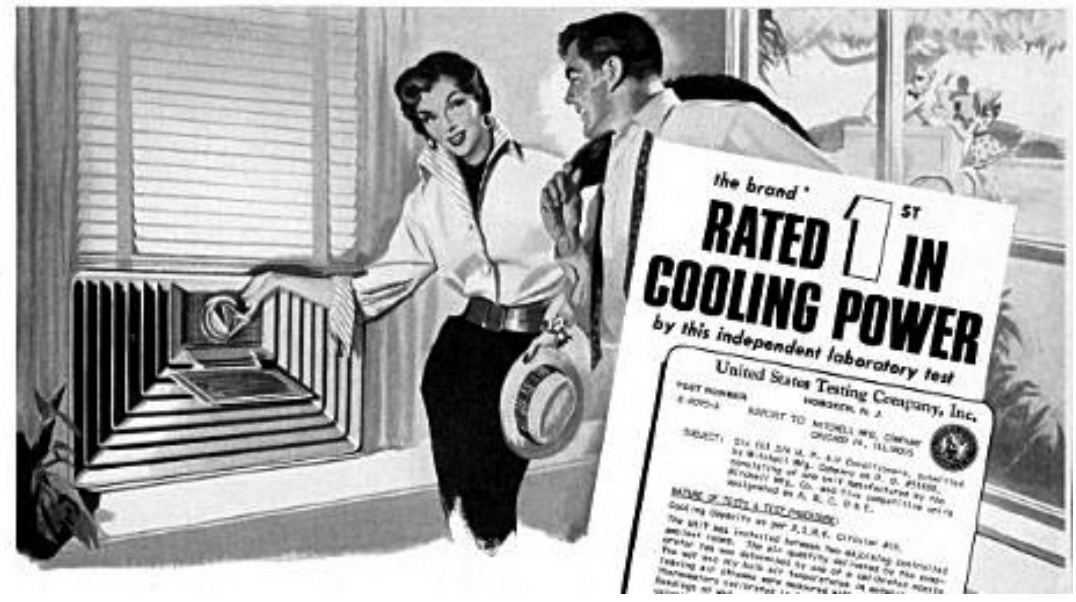

Figure 4: "Now . . . Beauty \& Comfort-a room air conditioner that fits flat with the wall; no bulge ... it's a Mitchell." Mitchell ad. Life, June 7, 1954, 2.

And what could heat be other than the latest danger against which the home needed to guard itself? In a 1954 Mitchell ad, as a wealthy couple turned on the cooling unit in their house, the view from the window revealed a little girl buying ice cream to find a less efficient remedy to heat [Figure 4]. Highlighting the contrast was even easier for the auto industry, as climate control made its way into the car market. A 1953 Chrysler ad placed one of its air-conditioned models in the middle of the desert, the copy reassuring readers that "even in the blazing heat of the Mojave - or the stifling heat of humid cities - Chrysler Corporations can keep you cool in fresh air-with your car windows closed tight." 14

The "juxtaposition of items," as Marshall McLuhan noted in his early study of advertising The Mechanical Bride, was common at a time when consumers were still familiarizing with its language. The blunter the contrast, the more effectively the image would speak to viewers' subconscious rather than reason. The immaterial concept of coolness could therefore be grasped with greater ease when compared to its opposite, making hot and cool, in a way, inseparable antonyms. Color was clearly the easiest trick: Ford presented its air-conditioned model traveling through a red and yellow sunburned suburb with kids peeping into the blue interior of the vehicle [Figure 5]. Fedders seemed particularly keen on these chromatic exaggerations, given the Mars-like view from the window 


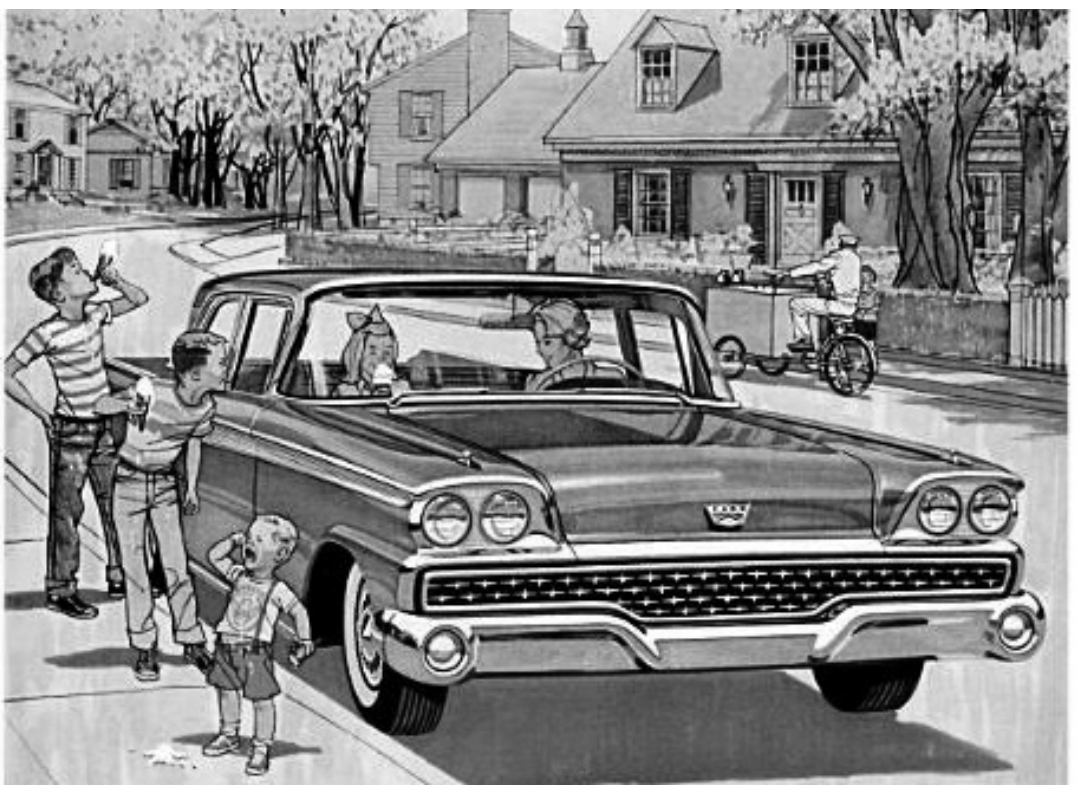

Figure 5: "Coolest car on the block (for up to $\$ 219^{85}$ less)." Ford Motor Company ad. Life, June 15, 1959, 86.

\section{FROM CARTON TO COOLING...IN 77.SECONDS}
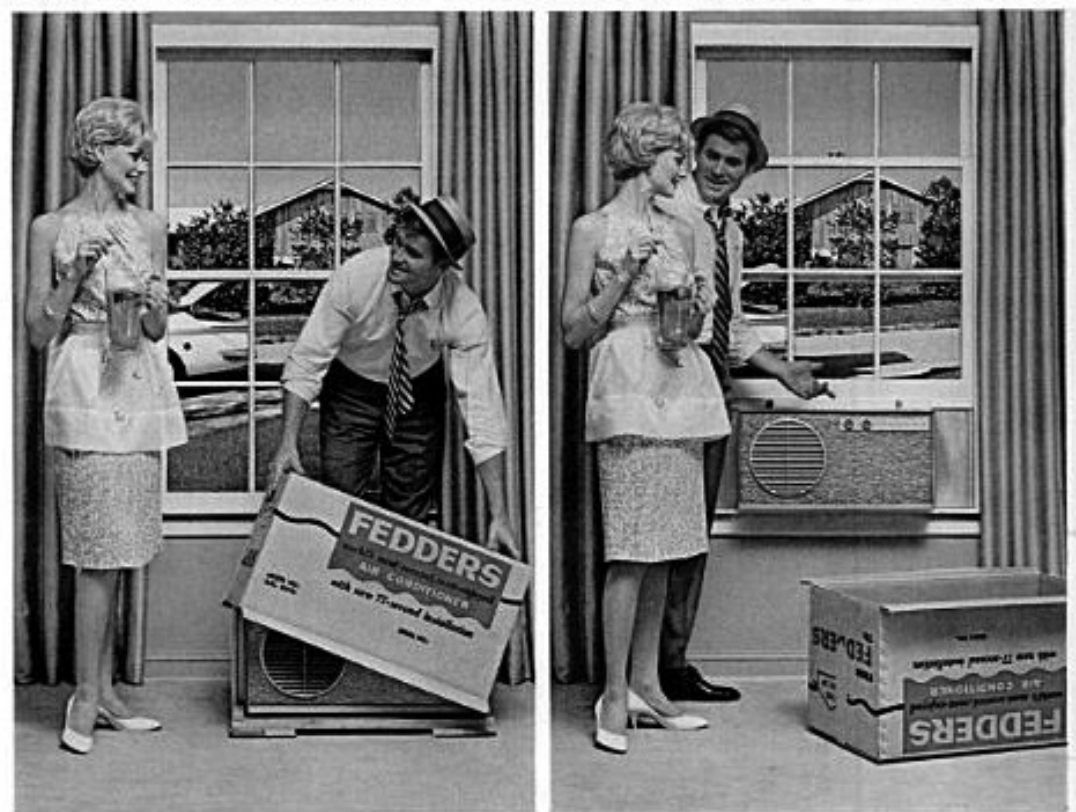

Figure 6: "From carton to cooling . . in 77 seconds." Fedders ad. Life, June 2, 1961, 114 . 
of a contented couple installing the new purchase on their blue wall in a 1961 ad [Figure 6]. In 1957, the contrast was slightly more understated: a housewife in a blue frock waved her husband hello from the turquoise-curtained window while, on the other side of the thin glass between heaven and hell, the man came home from work tiredly holding his jacket and clammy handkerchief, his pink shirt, red tie, and vermilion car conjuring up a drama of outdoor discomfort [Figure 7]. The ad also organized space according to the gender relations inscribed in suburban design, which presumed "the wife as the domestic worker, the husband as breadwinner" since the building of Levittown. The man returned from the public world, where his work provided for the family's needs, while the woman pined for her spouse at the window as a modern Rapunzel confined in the domestic interior. ${ }^{15}$

\section{Sitting Pretty ... Might Cool}

The use of colors provided the starting point for all the other antitheses that visually emphasized the clash between inside and outside as well as the fact that coolness equaled a betterment of the consumer's life. Climate-control advertising designated the outside as the space of labor against the leisure-driven

\section{Fedders "Thin...and Low" Air Conditioners} take $46 \%$ less space...save re-wiring costs...use less current

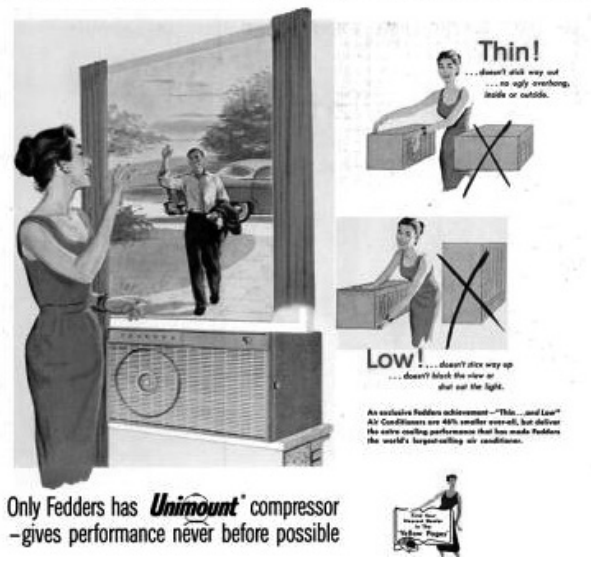

Figure 7: "Fedders 'Thin . . a and Low' Air Conditioners." Fedders ad. Life, April 22, domestic interior. Although home-design manuals advised home owners to use screening selectively to exclude visions of labor and the public realm (e.g., through orientation and curtains), in this instance, visions of the outside were retained to contrast with the interior as the locus of affluence. The husband in the Fedders ad was just back from work [Figure 7], and both the Ford and the Mitchell ads ([Figures 4 and 5] showed the ice-cream man as the only adult brave enough to face the outside world without air conditioning. In a 1958 General Electric ad, a sweaty postman outside an air-conditioned house smiled at the blue-dressed owner of the blue-painted house while she took a quick glance at her blazing yard [Figure 8]. Harrison, the air-conditioning division of General Motors, used this contrast in several ads: in one of them, the wealthy drivers of a blue GM conversed in a tropical setting with the ranger 


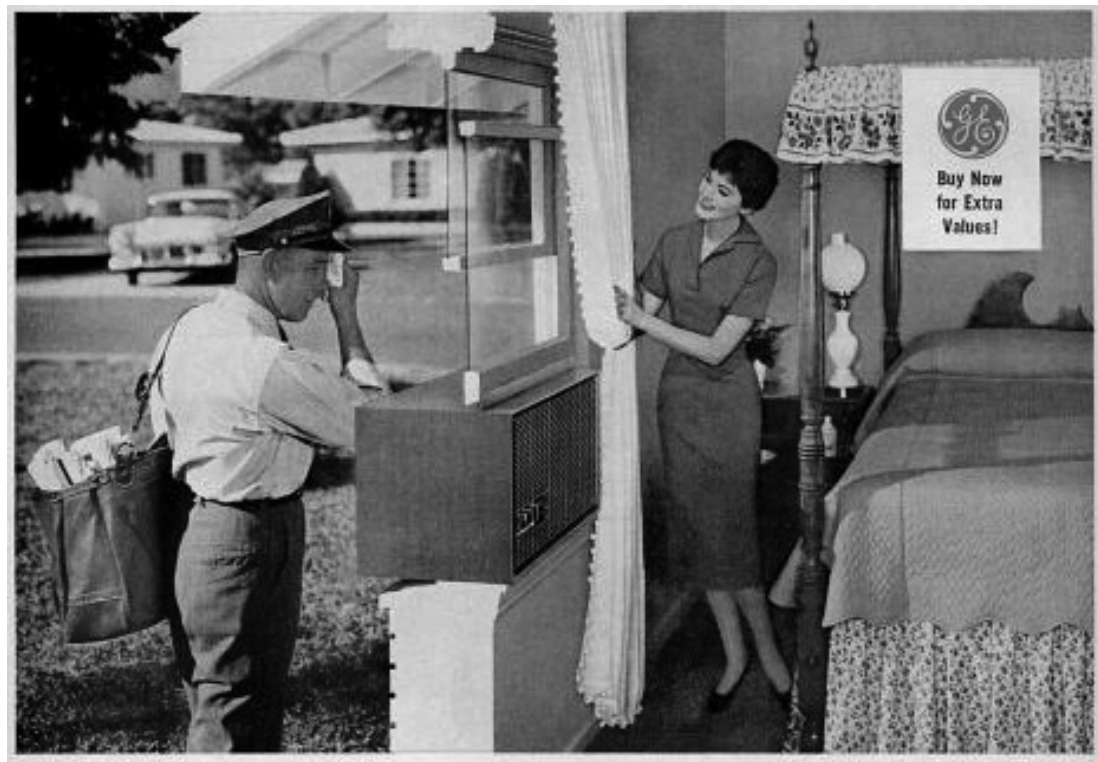

NEW KIND OF AIR CONDITIONER! THE GENERAL ELECTRIC CUSTOM THINLINE...

\section{0\% Smaller...Big-As-Ever Cooling Power}

Figure 8: “20\% Smaller . . Big-As-Ever Cooling Power.” General Electric ad. Life, June 30, 1958, 102.

who stood outside their car, drying the sweat off his neck. A valet deferentially opened their car door in another ad from the series, while they were "sitting pretty ... mighty cool" [Figure 9]. Gardeners were the members of the labor force most often associated with the heated-up outdoors. While they worked on the lawn, the air-conditioned family inside engaged in some leisurely activity, such as reading or playing [Figures 10 and 11]. The subtext was that coolness was more conducive to familial harmony once discomfort and domestic drudges were swept out of the house. ${ }^{16}$

These representations were not intended as a horizontal diorama juxtaposing social classes and their thermal conditions one next to the other. Since modern suburban living was meant to democratize welfare through generalized upward mobility, the discourse of cool leisure and hot labor was articulated as a vertical narrative that placed the climate-controlled interior at the top of the ladder. In 1945, a Westinghouse ad in Boy's Life presented air conditioning as the latest chapter of progress in a one-page comic. Each frame chronicled the course of human evolution through its quest for thermal well-being, from cavemen gathering around a fire to the Roman emperor Antoninus surrounded by blocks of ice and fan-waving slaves. The tale closed on the world of tomorrow: 


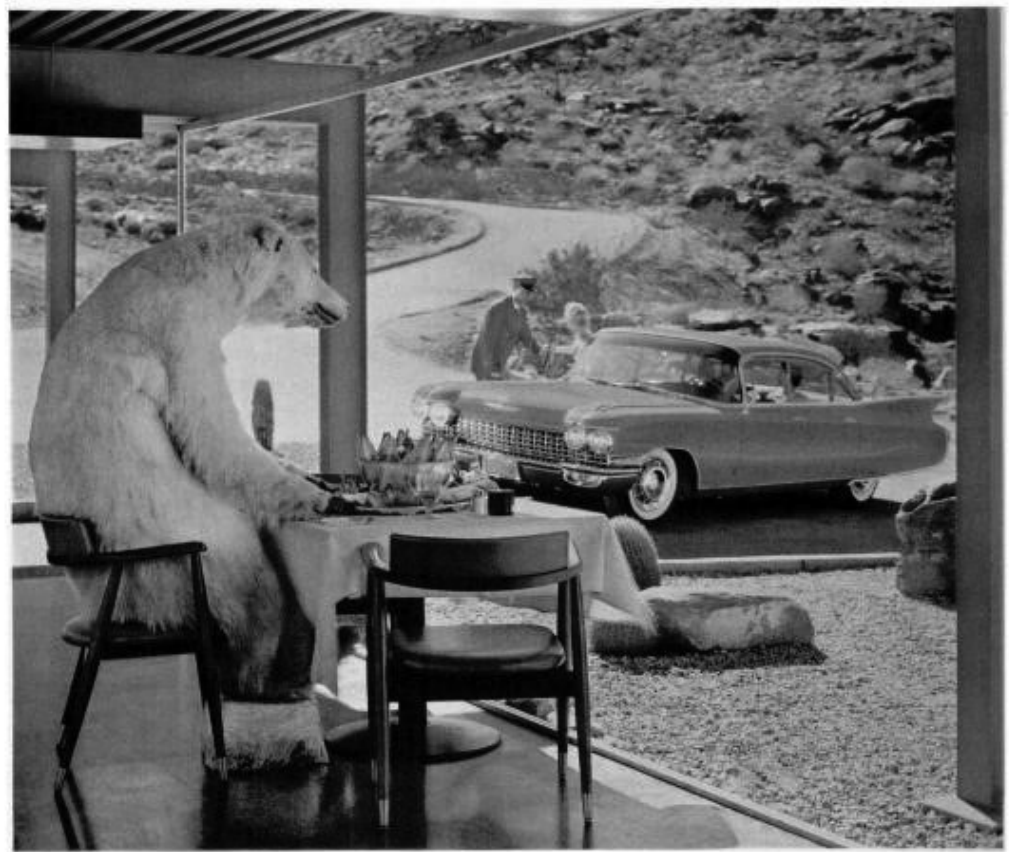

sitting pretty ... mighty cool!

If you like an air of cosol cambert... you'll love Harrives Air

Coeditioning in your new GM car? It will ald cool zest to your drivine wherever you go-eross city of cross eountry. With a flick of a switeh. you're sitting pretty, mighty cool ... eves during the tiesling vemmer montha! Yoe arrive an you drive-freeth as a dainy and ready for fun. Ote ride... you vil decile that Harrison Air Conditioning poes with your way of life! Your car radio and your coeversation take on a new intimate tooe. Sticky bumidity, rood and wind noise ere locked out. Your elothes and hair stay perfertly gromed. Every day is as rane at a day in June in a Harrison Air Coenditioned GM rar. Harrienn Air Conditioning in engineered

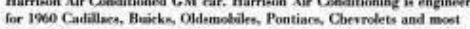
Cbevrolet trueks. Far a fresh new viewpoint con driving, get into a

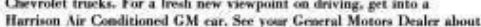

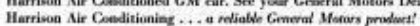

Add zest to your driving get GM car air conditioning!

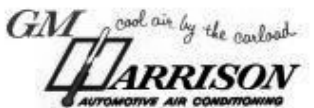

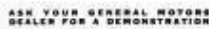

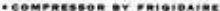

MARRISON RADIATOR DIVISION, GENERAL MOTORS CORPORATION. LOCKPORT, NEW YORK

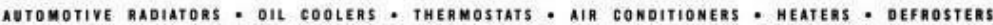

Copyrighted material

Figure 9: "Sitting pretty ... mighty cool!" Harrison Radiator Division—General Motors Corporation ad. Life, May 16, 1960, 144.

a mother with her two kids happily enjoying the benefits of the Westinghouse air conditioner in their living room [Figure 12]. ${ }^{17}$

It was up to consumers to choose whether they wanted to emancipate themselves from the "jungle curse," the catchphrase of a 1949 Carrier ad portraying a fatigued white adventurer sweltering in the equatorial heat under siege by 


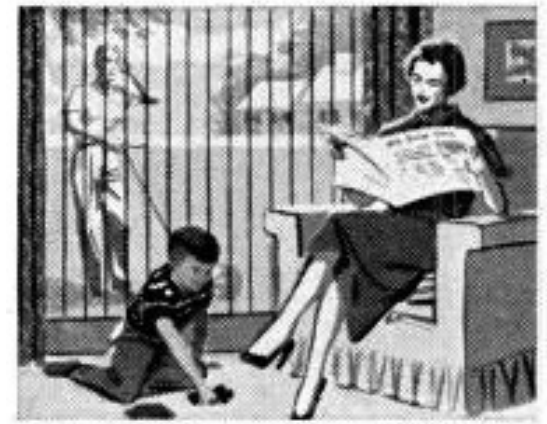

Figure 10: "Will your new home be obsolete ... even before you move in?" Borg Warner Engineering Production ad. Life, December 19, 1955, 7.

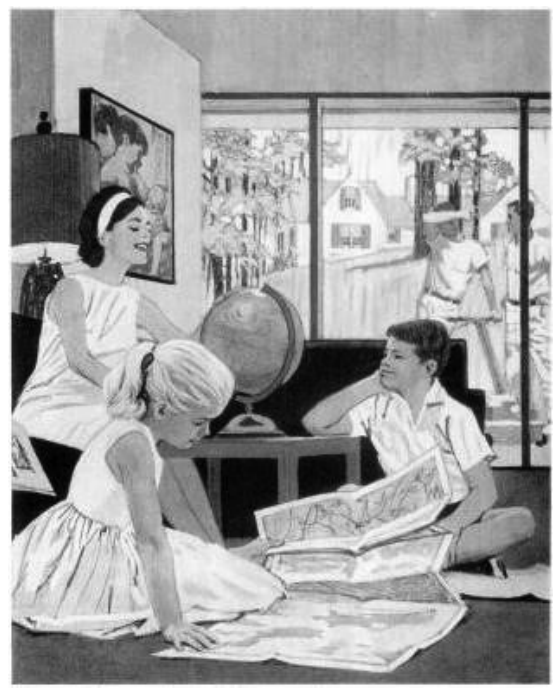

Figure 11: "For your family's year 'round comfort ... Gas air-conditioning." Blue Star Home ad. Life, July 16, $1965,86$.

African vendors clothed in tribal outfit. Another ad from the same series turned to the ethnic stereotype of the dull Mexican dozing off in the streets with only his sombrero to shield him from the scorching sun. Slaves from an ancient kingdom fanned their emperor in a smaller picture below next to the ultimate achievement in history: affluent Americans leisurely enjoying dinner in an upscale air-conditioned restaurant [Figure 13]. To promote man-made coolness as the latest stage of development, the industry drew on Ellsworth Huntington's theories. A Yale geographer, Huntington theorized in 1915 a relationship between cool or semicold climates with higher records of civilization in his successful study Civilization and Climate, citing heat and humidity as the major reason why some world regions lagged behind others in terms of socioeconomic advancement. In Huntington's view, the United States inconveniently spanned from mild to searing temperatures that could hinder an even development. ${ }^{18}$

The theory was taken up in 1934 by Clarence A. Mills, professor of experimental medicine at the University of Cincinnati, who advocated the use of climate control to counteract this risk. The perfect temperature, somewhat equaling that of the northern states, had made those Americans proactive individuals graced by a "vital, interested bearing" and an "urge to be on the go" and a "cleareyed breezy character." Not so for "darkest Africa," which had "little to offer for human development" given the plight of "the depressing moist heat of the tropics." Carrier's sluggish Mexican and jungle denizens were only paying the debt of being born in the wrong climate. America's technical ingenuity could enfranchise its populace from the same lot. In this respect, climate-control advertising was instrumental in linking whiteness to a more affluent and desirable 


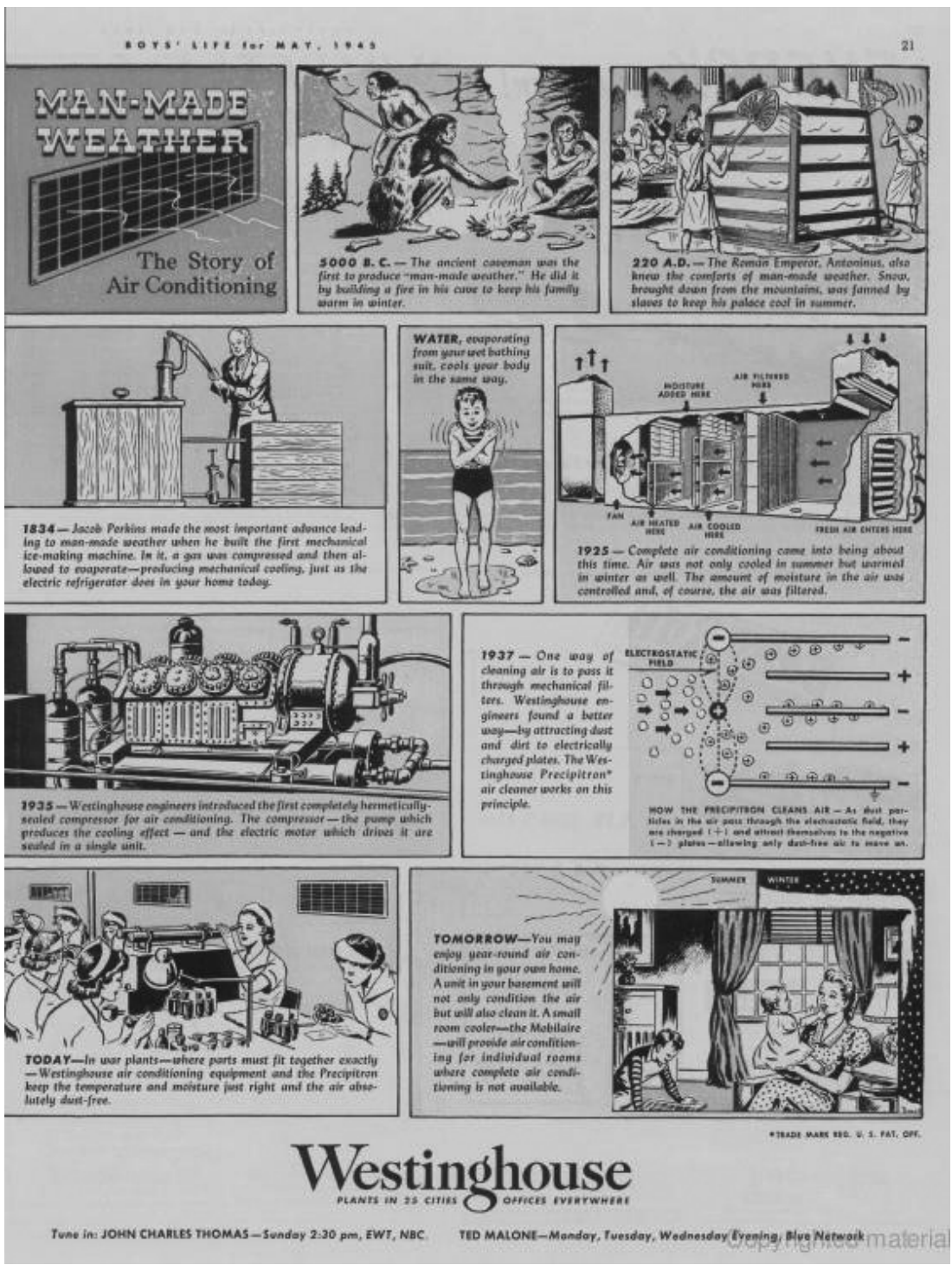

Figure 12: "Man-made Weather: the Story of Air Conditioning." Westinghouse ad. Boy's Life, May 1945, 21.

leisure-driven lifestyle. It does not take much perusal to notice the contrasting complexions between the outdoor workforce and the air-conditioned residents of the interior. In a later study titled Climate Makes the Man, Mills explored the health hazards of the modern urban environment, saturated by man-produced fumes. "For years I have driven from bright suburban sunlight down into the 


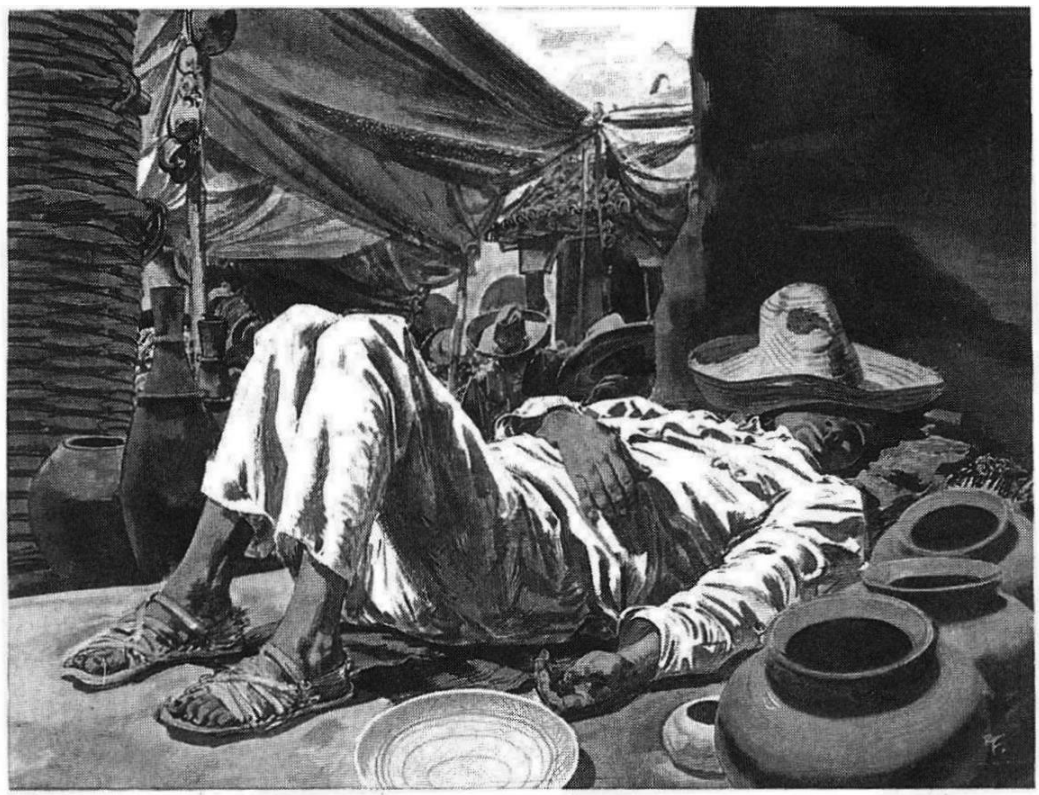

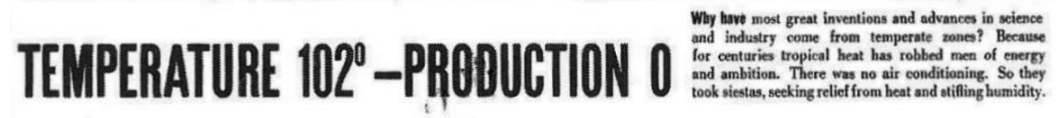

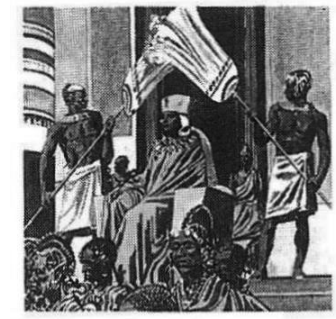

Ancicat despols tried to beat the heat with fan war. ing. Slaves made this a cheap way to keep air in motion, but without modern air conditioning nothing could be done to remove humidity. Nor could fans filter dust, pollen, other impurities.

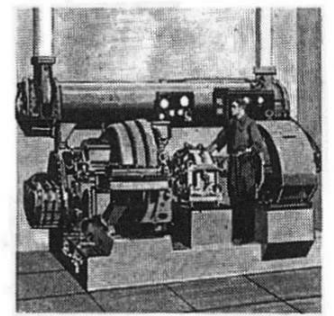

Heallitul indoot weuther - that's what this Carrierdeveloped centrifugal retrigerating machine gives man the world over. It is the heart of air conditioning systems providing comfort to hundreds of hotels, office buildings, stores, stearnships.

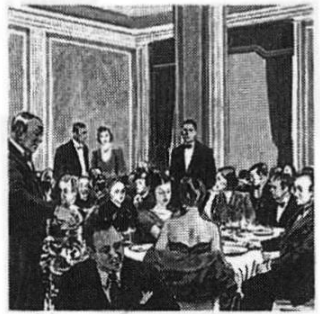

Diaing out is a real pleasure when cool, clean, $x$ freshing weather in the restaurant is furnished by Carrier. And there is a type of Carrier Air Conditioning to give you the same bracing climate in retail shops, in your office and your home.

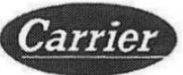

AIR CONDITIONING - REFRIGERATION

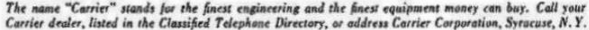

Figure 13: "Temperature 102'-Production 0." Carrier Corporation ad. Saturday Evening Post, February 12, 1949, 9.

dense murk of the basin area," he bemoaned, and "have wondered how long the people in our American cities would continue to tolerate such pollution of the air they breathe." He proposed that a "method of handling the problems of our surroundings is to escape from them into that form of localized artificial climate known as air conditioning." Suburbanization and the climate-control 
technology were equally instrumental in the postwar flight from the city and pursuit of insularity. ${ }^{19}$

Besides toxic exhausts, the flamboyantly dressed high society in the last frame of Carrier's ad had sidestepped both the drudgery of labor and the dangers of sloth. The two opposites were curiously paired up at the antipodes of the languid and yet productive American way of life, implying that air conditioning could generate a state of perpetual leisure in the interior. Civilization was, all in all, the attainment of leisure, and this could happen only in thermal well-being. The association of coolness and leisure dated back to the prewar years, when air conditioning was almost exclusive to entertainment venues and thermal comfort was used to discourage customers from leaving the premises. When cool air spread to the domestic environment, so could the leisurely activities that replaced house chores thanks to the self-sufficiency of the push-button house.

Women, as the guardians of the refrigerated hearth, posed some problems in Mills's analysis. Some of them did not seem to find comfort even in the perfectly balanced conditions of the cool interior. He quickly dismissed them as "burnt-out, neurasthenic wrecks" who "smolder along through a complaining miserable existence, chilling easily and dreading cold weather." They were certainly not to be taken as an example. As gender segmentation became a common marketing practice in the 1950s, Madison Avenue directed all its efforts into convincing female consumers, the most skeptical segment, of the benefits of climate control. The pros of working in an artificially cooled environment were already extolled in a 1937 Kelvinator ad that showed a window cleaner advising a sweating clerk that the new technology could improve his working conditions. The same convenience could now be replicated for women in their domestic workplace. "More leisure time-less housework" was RCA's catchphrase: closed windows would keep out "dust and dirt that make housework so endless." A 1954 study on the effects of air conditioning on households led by the National Association of Home Builders and the University of Texas highlighted the benefits of climate control on its users, among which was an increase in the number of housewives' hobbies from four to nine. ${ }^{20}$

Or, man-made coolness could lighten the burden of labor to the extent that it could feel like another pastime. Since the improvement of living conditions for middle-class Americans also meant that housework could no longer depend on servants, because the labor force was not enough to meet the rising demand of an expanding affluent society, the shift of its burden to housewives called not only for the mechanization of domestic work but also for its disengagement from labor as a notion linked to toil and lower status. Henthorn defines this popular advertising trope as "the myth of labor saved": through images and words, Madison Avenue claimed that this housework revolution allowed for the advancement of the middle class by fostering an allegedly leisurely lifestyle. The role of the housewife shifted to "overseeing electric servants ..., which lent her housework a glamorous rather than an arduous aura." As Susan Strasser has highlighted, labor-saving technologies for housewives (or those who made 


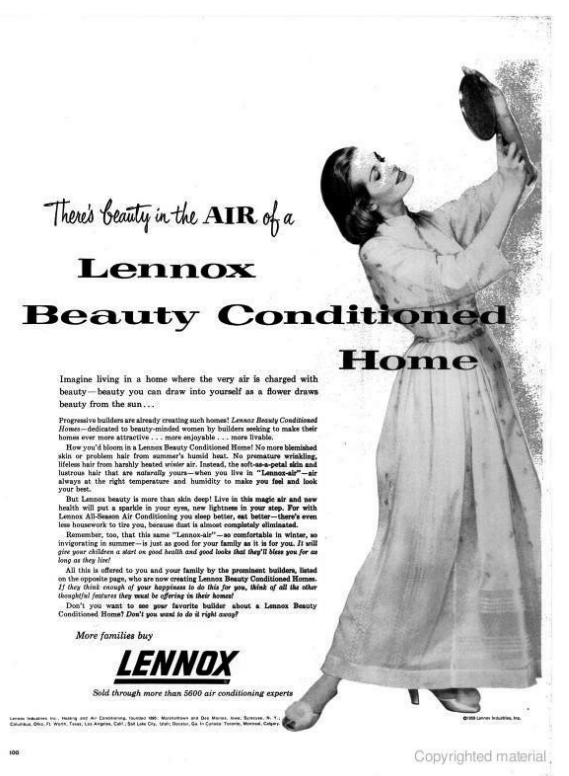

Figure 14: "There's beauty in the air of a Lennox Beauty Conditioned Home." Lennox Industries Inc. ad. Life, July 9, 1956, 100. housework more agreeable, as is the case of air conditioning) mirror the improvement of working conditions that historically affected most laborers through the twentieth century. In the housewife's case, however, this technological empowerment and self-sufficiency specifically resulted in her increased isolation from the social sphere. This was not always the case. Examining how the idea of housewife was constructed in the 1920s, Elizabeth Diller underlines the era's assumption that "the application of laborsaving techniques from scientific management, in conjunction with the introduction of household appliances ..., would release the woman from the home and thus enable her to join the paid labor force." But the technology implemented in the postwar suburbs, instead of acting as an instrument of emancipation, was presented as one ensuring an unlimited amount of spare time that women could enjoy only within the boundaries of the domestic interior. In the intricate system of metaphors that populated climate-control advertising, the removal of dust signified the eradication of labor from the domestic territory. Diller argues that "dirt soon became a moral construct yielding sexual, religious, and aesthetic distinctions"; advertisers usually mentioned it along with dust as housewives' worst enemy. In these dynamics of gendered space, "the fetishization of hygiene blurred the problem of cleanliness with beauty, chastity, piety, and modernity."21

The delighted women enjoying the benefits of air conditioning were physically enhanced by the chilled beauty acquired through perpetual free time. "Imagine leaving in a house where the air is charged with beauty - beauty you can draw into yourself," read the copy of a 1956 Lennox ad in which a housewife more akin to a Hollywood star contemplated her own image in the mirror [Figure 14]. An artificially cooled house could elevate her to the status of a diva like the ones found in the Carrier Silhouette series, the defeat of heat and sweat enabling her to embrace glamour [Figure 15]. She could "live like a queen in a house that takes care of itself," the American Gas Association suggested in 1944. Leisure, rather than her inclusion in the workforce, was the insignia of female liberation. Another more subtle innuendo was the cool air's potential 


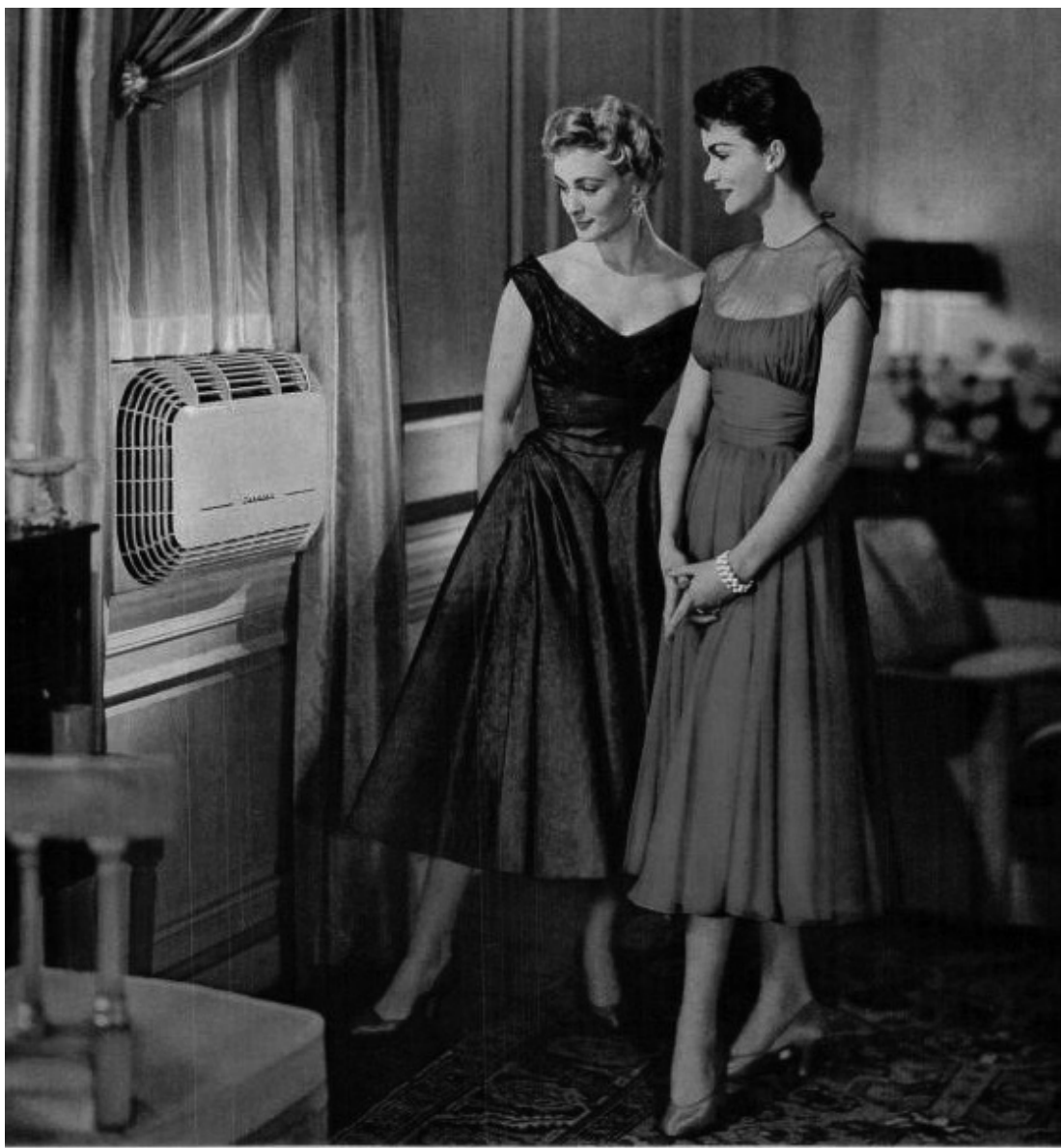

\section{THE NEW SILHOUETTE Carrier ROOM AIR CONDITIONER}

BUILT BY THE PEOPLE WHO KNOW AIH CONDITIONINO BEST, CARAIEH CORPOAATION, SYMACUSE, NEW YORK

Copyrighted material

Figure 15: "The New Silhouette Room Air Conditioner." Carrier Corporation ad. Life, July 12, 1954, 55.

to increase sex appeal or even serve as a seduction ploy, drawing on the timeless fusion of temperature extremes and sexual desire. It is air conditioning that leads Marilyn Monroe's character to spend a torrid New York night in her neighbor's apartment in Billy Wilder's 1955 comedy The Seven Year Itch. ${ }^{22}$

The cool interior was ultimately shown as a way to democratize luxury. If, as Roland Marchand contends, Depression-era advertising restricted its target to the upper classes through a widespread display of wealth that made most read- 
ers gape at an impossible dream, in the burgeoning postwar economy, Madison Avenue presented the life of Riley as yet another affordable commodity. For Lears, the advertising industry constructed "narratives of adjustment to a single, efficient system," and in the process of improving the lifestyle of the expanding middle class, luxury had to be downgraded from privilege to necessity. It was another form of conspicuous consumption but one that could expand the limits of the leisure class from Veblen's inner circle to broader social latitudes. Such visual associations thus went far beyond selling cool air. They embedded the physical states of coolness and heat - and the interior through which they could only be attained - in a hierarchy of positive and negative human activities. ${ }^{23}$

\section{The Great Outdoors Has Come Home}

The first casualties of this divide were clearly the natural climate and the exterior. In 1954, House Beautiful editor Joseph Howland wrote in an office memorandum that "the revolution set off by air conditioning is sweeping away outdoor living just as fast as it caught on after the war." In the same year, House \& Home released a special supplement to the March issue praising the comforts of fully air-conditioned houses with indoor gardens and sealed windows. As an article recounted, the owners of one such house "discovered that air-conditioning was so pleasant that he and his housewife almost never use their outdoor terrace." Windows could be happily shut to the world outside - even better, they had to be. In the air-conditioned society, the outside posed a threat to air conditioning itself. In 1966, Carrier condemned windows as undesirable leaks in a dwelling whose old design did not meet the requirements of the new technology [Figure 16]. As early as 1934, Clarence A. Mills advised his readers against the harmful "fetish for open air sleeping": the excessively

Figure 16: "Some homes are almost impossible to air condition." Carrier Corporation ad. Life, July 22, 1966, 63. cold night air could spoil the development of the vitalistic individual. 
Open air was increasingly seen with suspicion or fear; the exterior was shown only in contrast to the idyllic cool interior. Copies described the outdoor environment as a source of disease and threat, an enemy of the sanitized suburban house. Dust and pollen were invariably targeted as the plague of the twentieth century. The discourse on sanitation implied that assimilation into the middle class fostered "America's alchemical transformation into a pure and hygienic society free of friction and chaos," a common thread of postwar marketing in Henthorn's analysis. ${ }^{24}$

In his 1957 polemic against marketing strategies, The Hidden Persuaders, Vance Packard called attention to an inherent problem that an advertising agency found with such portrayals of the outer world. Their research evidenced that although some buyers, the "womb-seekers" who were subconsciously in need of protection, found the shut windows and the concept of a hostile outside appealing, many consumers suffered from "a latent claustrophobia." "For those of us in this class the conditioner, far from being a symbol of security, becomes a threat"; "its sealed world gives us a feeling of being closed in." Already in 1948, the Carrier Corporation viewed America's eagerness for out-

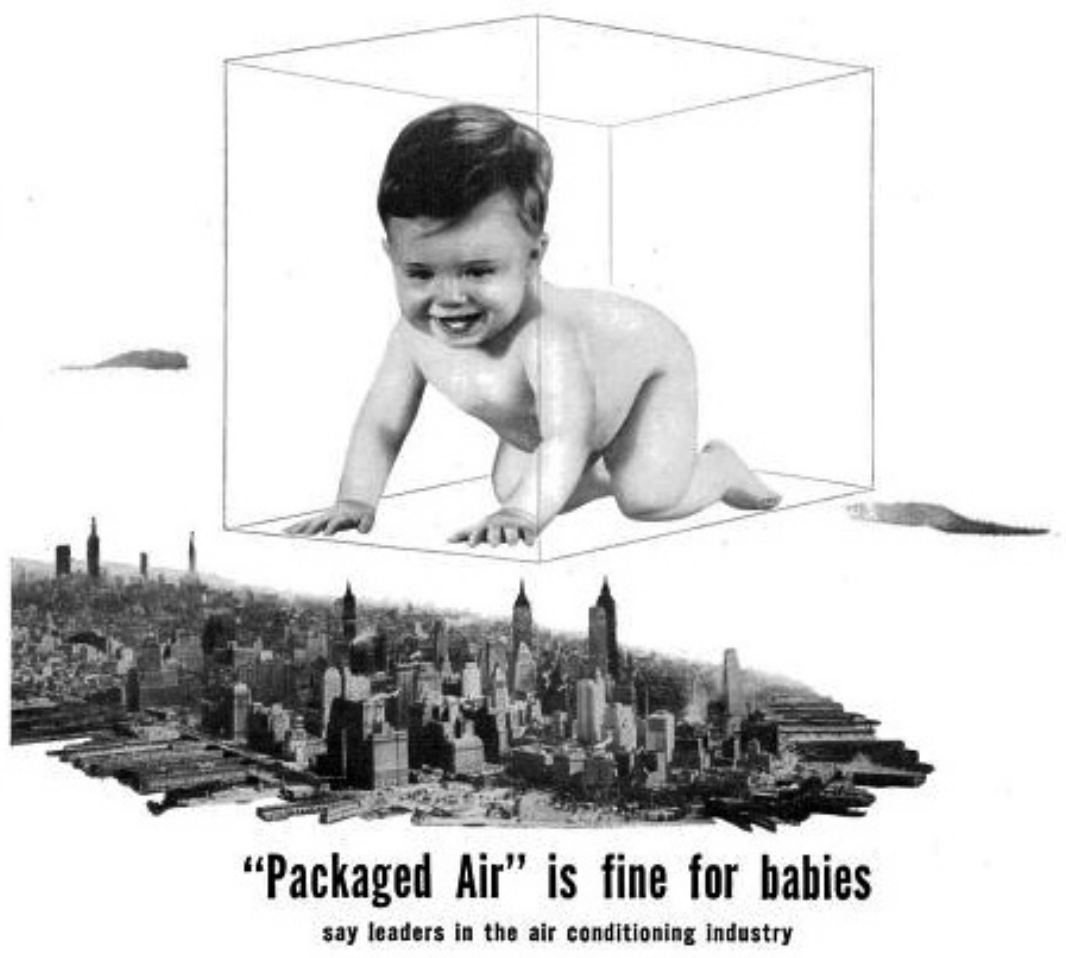

Figure 17: "'Packaged Air' is fine for babies." Revere Copper and Brass Inc. ad. Life, January 24, 1944, 61. 


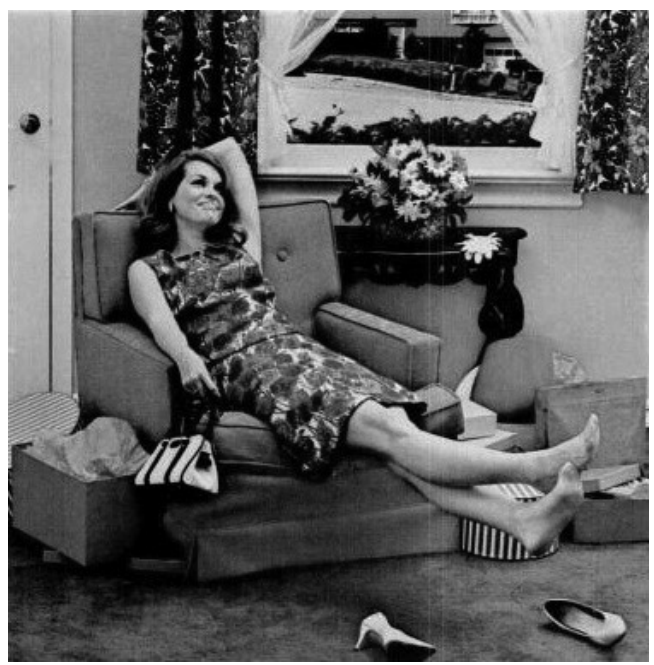

Figure 18: "Crosley cleans as it dries as it cools the air comfortably!" Crosley ad. Life, June 22, 1953, n.p. door living as an obstacle for sales. That many could see the necessity of closing windows as a form of imprisonment was likely to raise issues in the private home market. For example, a 1955 Borg-Warner ad explained to readers that their air-conditioning system could be enhanced by "narrow bronze strips, deflected to a precise angle": the family had to be barred inside for the sake of technology [Figure 10]. The air-conditioned man was often portrayed encapsulated in vortexes and bubbles: a King Kong-size infant hovered in a giant box in the Manhattan skies in a 1944 Revere $\mathrm{ad}$, reassuring customers that "packaged air is fine for babies" [Figure 17]. ${ }^{25}$

To conceal these claustrophobic properties, ads suggested that man-made weather could in fact re-create en-plein-air conditions in the domestic space. A 1953 Crosley ad showed actress Margaret Lindsay flaunting the company's new air conditioner. Although a few tree branches were barely visible through the shaded window, a more luxuriant vegetation could be found inside the house in the curtain pattern as well as the vase in the forefront [Figure 18]. In the first half of the 1950s, Crosley started to use the "cool-as" slogan, suggesting that their air-conditioning unit made customers as "cool as living by a lake" or "as sleeping in the mountains," in plain words, as cool as if nature had physically entered the house. The graphics showed beds floating in the midst of a mountain range and kitchen tables on the lakeside. A 1968 York ad featured a woman leisurely enjoying the cool interior after some shopping. Indoor natural references reached the level of horror vacui, with the floral pattern of her green sundress, the flower bouquet on the table sitting next to her, and the intricate motifs of leaves and blue flowers on the window curtains framing the yellow and red outdoors, where a few hedges matched the green interiors [Figure 19]. The air conditioner is not visible, but the coolness of the air is. ${ }^{26}$

Investing air conditioning with the ability to replicate the freshness of the open air fostered the idea that nature had become unnecessary. What use was the outdoors when the technology was "introducing the great indoors"? In the 1968-1969 Lennox campaign, the house opened up like a book in an arcadian scenery of lakes, ducklings, and forests [Figure 20]. "The great outdoors has come home," the company announced, boasting the technology's ability to 


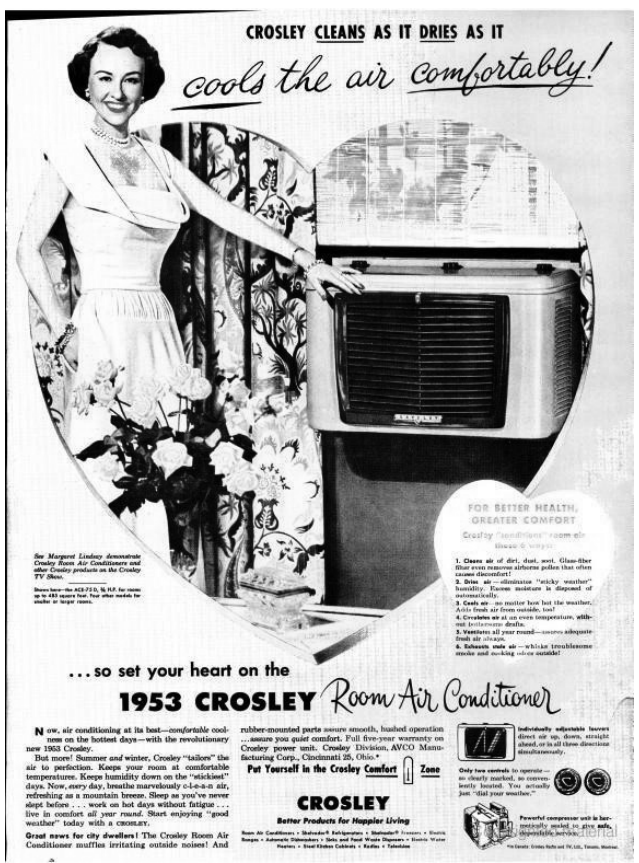

Figure 19: "Plan now for next summer's comfort!" York-Division of Borg Warner Corporation ad. Life, September 27, 1968, 105. reproduce "a spring day in the country" to reassure the muchfeared latent claustrophobia of potential customers. If the Crosley and York campaigns relied on more subtle undertones, Lennox physically tore down the domestic boundaries but only in the realm of advertising metaphors. ${ }^{27}$

In this respect, the visual advertising of air conditioning presents a perfect case of how postwar suburbia disguised the increasing interiorization of everyday practices that its lifestyle implied behind an idealized notion of outdoor living that was illusory at best. As Sandy Isenstadt has demonstrated in his analysis of the mid-century single-family house, the suburban ideal of indoor-outdoor living was more often than not a matter of optical perception rather

than physical experience. Openness was suggested by visually bringing the outside in through picture windows, open-plan design emphasizing continuity over separation, or ad hoc orientation focusing on pastoral views and escaping signs of human presence whenever possible. Commenting on Levittown as the prototype of suburban America, cultural historian Peter Bacon Hales read it as "a paradigmatic Cold War landscape, simultaneously huddling place and open community, with neither extreme particularly far from the other." 28

The use of spaciousness as a visual cliché to advertise suburbs and the products marketed to its residents highlights this paradox behind openness and insulation, clearly evidenced by the dichotomous representations that Madison Avenue used to sell the climate-control technology. Even model houses on display at fairs or published in homemaking and architectural magazines were tellingly conceived as "hyperinteriorized spaces," as Beatriz Colomina has argued, exemplifying how "the house steadily excluded more and more of the outside world as the twentieth century proceeded." In this context, air conditioning served as the very oxygen of the new suburbs and the bedrock of any discourse on autonomy from the exterior. "Is it really surprising that the public's often noted withdrawal into self-pursuit and privatism has coincided with the epic spread of air conditioning?," Time columnist Frank Trippett asked in 1979. ${ }^{29}$ 


\section{Introducing the great indoors}

You enjoy a carefree fresh-air climate in your home all year with a Lennox Electric Total Comfort System.

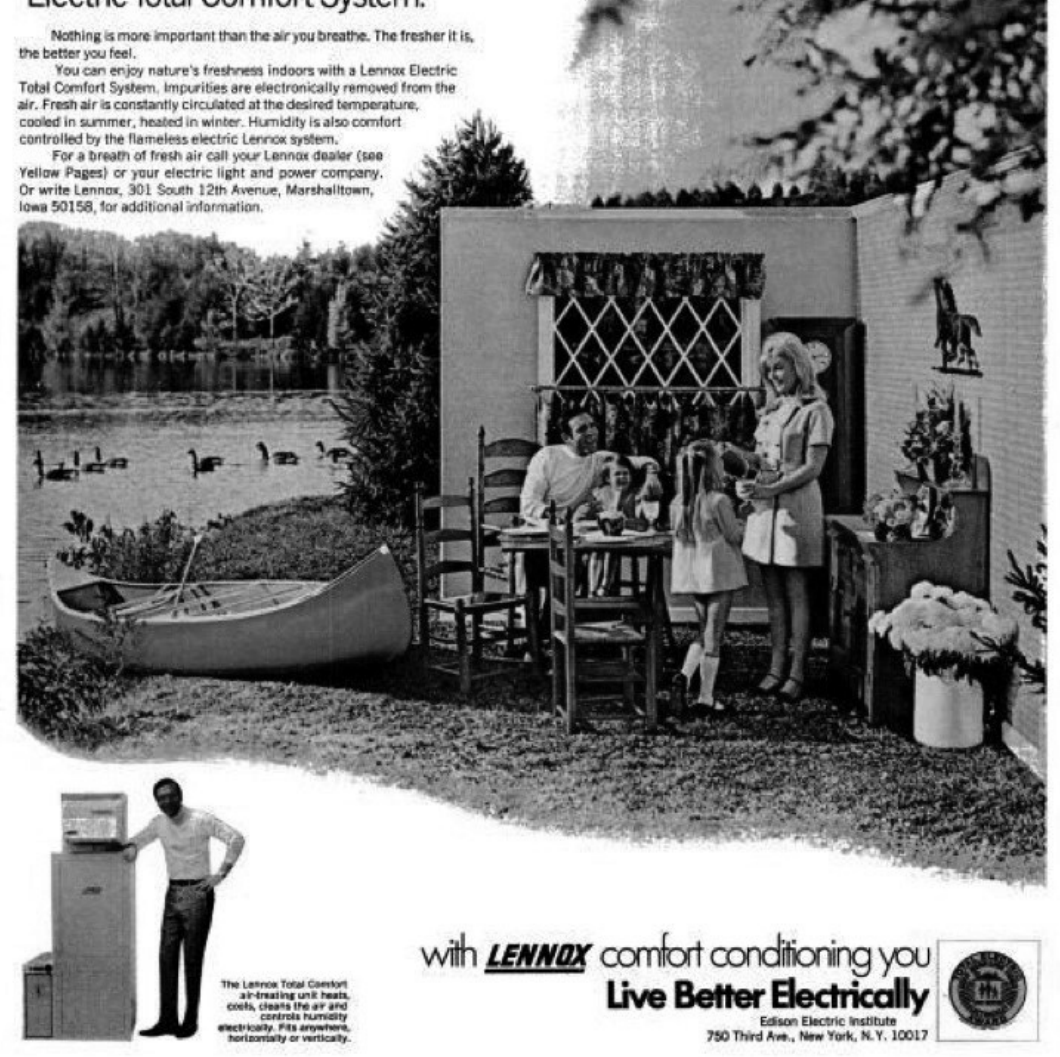

Figure 20: "Introducing the great indoors." Lennox Live Better Electrically ad. Life, March 7, 1969, 41.

This mode of living has survived long after the end of postwar atomic fears and economic prosperity. As historian John Archer notes, Americans' chasing of the suburban dream has often coincided with a headlong pursuit of even greater isolation - through distance, barriers, or both - the better to ward off forces that could despoil the dream. Such efforts have been instrumental in the endless advance of suburban sprawl, the rising popularity of gated communities, the fashion for "cocooning," and even the rash of commercials for 
sport-utility vehicles (conspicuously marketed to suburbanites) emphasizing the vehicle's capacity to isolate the driver from the stresses and pressures of the surrounding world or to serve as an "escape" vehicle altogether. ${ }^{30}$

Backyards offer little relief from the suburban landscape of "continuous interiors," as historian Mark Pimlott has termed the dominant form of US architecture brought about by car dependency, in which two-thirds of Americans now live. For most suburbanites, the outdoors is now a concept linked with recreation culture rather than routine. It is merely another place to go to, whether in the form of a jog, a stroll in a new open-air mall, a barbecue party, or a national park: a lifestyle choice rather than part of ordinary life. Concurrently, climate control is now standard in all automobiles as well as public facilities. As for the private home, the number of air-conditioned households has escalated since the manufacturers' expansion into the private market from less than 2 percent in 1955 to 68 percent in 1993 and 87 percent in $2009 .{ }^{31}$

These developments have little to do with local climatic factors. Take southern California, one of the most heavily car-dependent, suburbanized, airconditioned metropolitan areas in the nation but also one where weather would make climate control less needed. Its case shows how air conditioning was not so much devised as a solution to climatic extremes; it simply ensured that local climatic conditions would not stand in the way of the new standardized landscape. Economic historian Jeff Biddle has noted that the spread of residential air conditioning, as a leveler of regional differences, "had a profound impact on the distribution of population and economic activity in the United States." The economic boom in the South and its rapid suburbanization could not have come to being without indoor cooling systems, as historians Raymond Arsenault and Carl Abbott note. The climatic self-sufficiency enabled by the technology allowed for the growth of regions that few would once have deemed inhabitable. Whether in Alaska or Arizona, suburbanites reside in fairly similar environments because weather is no longer a concern. One can live in a Cape Cod house in California or a ranch house in Connecticut, shop in windowless big-box stores and malls, park in their underground facilities, and travel at a constant temperature wherever the freeway is taking them. Although there is no mention of the technology in Henry Miller's 1945 The Air-Conditioned Nightmare, the evocation of climate control in the title is enough to capture the book's central critique of the separation between the human and natural environments, which would reach a pinnacle in the suburban car-house-mall complex. It is the same critique that architectural commentator Bernard Rudofsky articulated in the other quote opening this article, taken from his witty examination of postwar domestic life in American suburbia, Behind the Picture Window. ${ }^{32}$

The postwar advertising of air conditioning thus stands as evidence of how Madison Avenue helped Americans adjust to this new suburban landscape. This was done through visual strategies that set interiors and exteriors in contrast and made the former look more appealing in the consumers' eyes by means of specific associations. It provides a perfect example of the role that popular 
images play in shaping culture and the everyday use of space. Air conditioning lured many Americans inside in search for affluence, upward mobility, technological development, and beauty, not just for shelter from heat and humidity. The technology kept interiors cool, but it was advertisers who made interiors the cool place to be.

\section{Notes}

1. Henry Miller, The Air-Conditioned Nightmare (London: Heinemann, 1962), 10-1. 1955), 150.

2. Bernard Rudofsky, Behind the Picture Window (New York: Oxford University Press,

3. "Air conditioning: After the war it will be cheap enough to put in private homes." Life, July $16,1945,39$.

4. On advertisers' difficulties in the visual representation of air conditioning, see Ackermann, Cool Comfort: America's Romance with Air-Conditioning (Washington, DC: Smithsonian Institution, 2002), 98-99. On images of refrigerators in postwar advertising, see Isenstadt, "Visions of Plenty: Refrigerators in America around 1950" Journal of Design History 11, no. 4 (1998): $311-21$.

5. "Dreams of 1946: Americans Yearn for Rosy Future of Rich Cars and Wondrous Homes," Life, November 25, 1946, 57-60. The main histories of air conditioning to date are Cooper, AirConditioning America: Engineers and the Controlled Environment, 1900-1960 (Baltimore: Johns Hopkins University Press, 1998), Ackermann (2002), and Basile, Cool: How Air Conditioning Changed Everything (New York: Fordham University Press, 2014). The historiography of postwar suburbs is too extensive to provide a full list here; for an overview, see Jackson, Crabgrass Frontier: The Suburbanization of the United States (New York: Oxford University Press, 1987), Fishman, Bourgeois Utopias: The Rise and Fall of Suburbia (New York: Basic Books, 1987), Hayden, Building Suburbia: Green Fields and Urban Growth, 1820-2000 (New York: Pantheon Books, 2003), Archer, Architecture and Suburbia: From English Villa to American Dreamhouse, 16902000 (Minneapolis: University of Minnesota Press, 2005), Beauregard, When America Became Suburban (Minneapolis: University of Minnesota Press, 2006), and Ross, Dead End: Suburban Sprawl and the Rebirth of American Urbanism (Oxford: Oxford University Press, 2014).

6. Lizabeth Cohen, A Consumers'Republic: The Politics of Mass Consumption in Postwar America (New York: Alfred A. Knopf, 2003), 195.

7. Susan Strasser, Satisfaction Guaranteed: The Making of the American Mass Market (New York: Pantheon Books, 1989), 95.

The first completely enclosed mall in the United States, Southdale Center, was designed by Austrian-born architect Victor Gruen and built in 1956 in Edina, Minnesota; see Hardwick, Mall Maker: Victor Gruen, Architect of an American Dream (Philadelphia: University of Pennsylvania Press, 2004).

8. Marshall McLuhan, The Mechanical Bride: Folklore of Industrial Man (London: Routledge \& Kegan Paul, 1967), v.

9. "The World's Fair Weather," Carrier Corporation ad in Time, May 8, 1939, 33. On Carrier's pavilion, see Ackermann (2002, 96-98). On Carrier's 1906 Apparatus, see Basile (2014, 88-94). On air-conditioning use in entertainment venues in the interwar years, see Cooper (1998, 80-109), Ackermann (2002, 43-61), Biddle, "Making Consumers Comfortable: The Early Decades of Air Conditioning in the United States," Journal of Economic History 71, no. 4 (December 2011): 1078-94, and Basile (2014, 105-30). On the spelling of the word "cool," see Frazier, "Air Conditioning," New York Magazine, June 26, 1995, 118. On air conditioning as a built-in component in new suburban housing, see Cooper (1998, 166-67).

10. Heating and Air Conditioning the Postwar Home (Minneapolis: Honeywell Company, 1944); Lears, Fables of Abundance: A Cultural History of Advertising in America (New York: Basic Books, 1994), 171. Srdjan Jovanovic Weiss, "Better Than Weather: The Austin Air-Conditioned Village" Cabinet 3 (Summer 2001): 106 explains that the subject of air conditioning already divided the general public in the interwar years. On how large builders and corporate industry fueled the model-house rhetoric at the end of the war, see Mennel, "'Miracle-House Hoop-La': Corporate Rhetoric and the Construction of the Postwar American House," Journal of the Society of Architectural Historians 64, no. 3 (September 2005): 340-61.

11. Jovanovic Weiss $(2001,104)$. Analyzing interwar advertising, Marchand in Advertising the American Dream: Making Way for Modernity, 1920-1940 (Berkeley: University of California Press, 1985), 25-59, discussed a wealth of ads selling consumer products through images of progress and futurism. On how suburbia has been informed by the republican tenets of privatism and individualism since the nineteenth century, see Archer (2005, 173-202). 


\section{Andrea Vesentini}

12. "I say it's heavenly ... The Boss says it's G-E air conditioning," General Electric ad in Time, October 4, 1948, 101; "Live Better . . Electrically," Live Better Electrically ad in Life, April 23, 1956, 30-31; "New Frigidaire Stereo Cooling," Frigidaire ad in Life, June 13, 1960, 124. About the widespread tendency to disguise the technology inside the house, Popular Science showed in 1955 that units could be camouflaged as a table or "tucked behind the window drapes and Venetian blinds" ("This Summer You Can Stay Cool-Wherever You Are," Popular Science, April 1955, 112.) explains, "The invisibility of air-conditioning posed marketing problems. In their eagerness to make the cooling equipment unobtrusive, fifties marketers were in danger of making its effects disappear into the background as well."

13. Heschong, Thermal Delight in Architecture (Cambridge, MA: MIT Press, 1979), 24; May, Homeward Bound: American Families in the Cold War Era (New York: Basic Books, 1988), 3. On how suburban design pursued a separation of domestic and public life, see, for example, Harris, Little White Houses: How the Postwar Home Constructed Race in America (Minneapolis: University of Minnesota Press, 2013).

14. "Now ... Beauty \& Comfort - a room air conditioner that fits flat with the wall; no bulge . . . it's a Mitchell," Mitchell ad in Life, June 7, 1954, 2. "Air conditioning your car," Chrysler Corporation ad in Life, July 27, 1953, 116. On the early days of automobile air conditioning, see Barclay, Boy! That Air Feels Good! (Charleston, SC: Createspace Independent Publishing Platform, 2013).

15. McLuhan $(1967,82)$; "Coolest car on the block (for up to $\$ 21985$ less)," Ford Motor Company ad in Life, June 15, 1953, 86. "From carton to cooling . . . in 77 seconds," Fedders ad in Life, June 2, 1961, 114; "Fedders 'Thin . . . and Low' Air Conditioners," Fedders ad in Life, April 22, 1957, 67; Kelly, Expanding the American Dream: Building and Rebuilding Levittown (Albany: State University of New York Press, 1993), 89.

16. " $20 \%$ Smaller . . . Big-As-Ever Cooling Power," General Electric ad in Life, June 30, 1958, 102; "GM car air conditioning. I presume," Harrison Radiator Division-General Motors Corporation ad in Life, February 8, 1960, 81; "Sitting pretty . . . mighty cool!" Harrison Radiator Division-General Motors Corporation ad in Life, May 16, 1960, 144; "Will your new home be obsolete ... even before you move in?" Borg Warner Engineering Production ad in Life, December 19, 1955, 7; “A New Refreshing Comfort-Appeal," Mueller Climatrol ad, in Ackermann (2002, 129); "For your family's year 'round comfort . . . Gas air-conditioning," Blue Star Home ad in Life, July 16, 1965, 86.. On how the Housing and Home Finance Agency in the early 1950s advised home owners to use screening selectively, see Isenstadt, The Modern American House: Spaciousness and Middle-Class Identity (Cambridge: Cambridge University Press, 2006), 240-42.

17. "Man-made Weather: the Story of Air Conditioning," Westinghouse ad in Boy's Life, May $1945,21$.

18. "Jungle Curse," Carrier Corporation ad in Saturday Evening Post, April 2, 1949, 111; "Temperature 102'-Production 0" Carrier Corporation ad in Saturday Evening Post, February 12, 1949, 9; Huntington, Civilization and Climate (New Haven, CT: Yale University Press, 1915); Huntington analyzed the relationship between climate and civilization in the United States through questionable measurements of vitality and education among the population. On how air-conditioning companies exploited Huntington's work for marketing purposes, see Ackermann (2002, 17-24).

19. Mills, Living with the Weather (Cincinnati, OH: Caxton Press, 1934), 11, 13-14; Mills, Climate Makes the Man (New York: Harper \& Brothers, 1942), 161, 198; Mills analyzed the case of urban pollution in a chapter titled "Shadows over Our Cities" (145-61). On how the design and representation of suburban interiors as well as discourses around domestic privacy bespoke white Americans' racial fears, see Harris, "Race, Class, and Privacy in the Ordinary Postwar House, 1945-1960," in Landscape and Race in the United States, edited by Richard H. Schein (New York: Routledge, 2006): 127-55 and Harris (2013).

20. Mills $(1934,67)$; "I say you'd get more work done if you had a room cooler like the guy next door!" Kelvinator ad in Life, June 7, 1937, 96; "Just as sure as you Live . . and Breathe . . you'll Live Better . . . Breathe Easier . . . with an RCA Room Air Conditioner" Radio Corporation of America-Victor Division ad in Life, June 23, 1952, 73; "Dig that real cool contraption! Texas tests show the effects of air-condition- ing-and how to use it properly," Life, August 8, 1955, 71-74. On the Austin experiment, see Cooper (1998, 154-55) and Jovanovic Weiss $(2001,104-7)$. On the rise of gender segmentation in postwar marketing, see Cohen (2003, 292-344). On how advertisers targeted women as a skeptical market segment, see Friedman, "The Air-Conditioned Century," American Heritage 35, no. 5 (August/September 1984): 32. Robbins, "Keeping Things Cool: AirConditioning in the Modern World," OAH Magazine of History 18, no. 1 (October 2003): 44, and Basile (2014, 197-98)

21. Henthorn, From Submarines to Suburbs: Selling a Better America, 1939-1959 (Athens: Ohio University Press, 2006), 185-91; Strasser, Never Done: A History of American Housework (New York: Pantheon Books, 1982), 9; Diller, "Bad Press," in Architecture: Reconstructing Her Practice, edited by Francesca Hughes (Cambridge, MA: MIT Press, 1996), 80. On the shift from servant to housewife labor starting from the $1920 \mathrm{~s}$, see Jessamyn Neuhaus, Housework and Housewives in American Advertising: Married to the Mop (New York: Palgrave Macmillan, 2011), 3-4. On the symbolism associated with dirt, see also Douglas, Purity and Danger: An Analysis of the 
Concepts of Pollution and Taboo (London: Routledge, 1966), 36.

22. "There's beauty in the air of a Lennox Beauty Conditioned Home" Lennox Industries Inc. ad in Life, July 9, 1956, 100; "The New Silhouette in Room Air Conditioners," Carrier Corporation ad in Life, April 12, 1954, 69; " . . . and I'll live like a queen in a house that takes care of itself," American Gas Association ad in Life, February 28, 1944, 21; The Seven Year Itch, directed by Billy Wilder (1955; Los Angeles, CA; Charles K. Feldman Group, Twentieth Century Fox).

23. Marchand $(1985,12)$. On leisure as a form of conspicuous consumption, see Thorstein Veblen, The Theory of the Leisure Class: An Economic Study of Institutions (New York: B. W. Huebsch, 1922).

24. Joseph Howland, quoted in Harris $(2013,290)$; House \& Home interview, quoted in Ackermann (2002, 122); "Some homes are almost impossible to air condition," Carrier Corporation ad in Life, July 22, 1966, 63; Mills $(1934,64)$; Henthorn $(2006,100)$. On the air-conditioning industry's increasing attempts to convince consumers that home design needed to be rethought in order to adapt to the technology, see Rome, The Bulldozer in the Countryside: Suburban Sprawl and the Rise of American Environmentalism (Cambridge: Cambridge University Press, 2001), 71.

25. Vance Packard, The Hidden Persuaders (Harmondsworth: Penguin, 1960), 67; "Will your new home be obsolete . . . even before you move in?" Borg Warner Engineering Production ad in Life, December 19, 1955, 7; "'Packaged Air' is fine for babies," Revere Copper and Brass Inc. ad in Life, January 24, 1944, 61. Boxed men floated among mountains in "Air Conditioning adds a New Dimension," General Electric ad in Business Week, March 20, 1943, 12. Vortexes dominated the Frigidaire campaigns; see "The Frigidaire Thrifty Twin gives you two room conditioners in one!" Frigidaire ad in Life, July 12, 1954, 31, and "New Frigidaire Stereo-Cooling" (1960, 124). On Carrier Corporation's concerns over how the love for the great outdoors could work against the air-conditioning market, see Ackermann $(2002,109)$.

26. "Crosley cleans as it dries as it cools the air comfortably!" Crosley ad in Life, June 22, 1953, n.p.; "Cool as living by a lake!" Crosley ad in Life, July 13, 1953, 112; "Cool as sleeping in the mountains!" Crosley ad in Life, July 27, 1953, 95; "Plan now for next summer's comfort!" York-Division of Borg Warner Corporation ad in Life, September 27, 1968, 105.

27. "Introducing the great indoors," Lennox Live Better Electrically ad in Life, March 7, 1969, 41. "The great outdoors has come home," Lennox Live Better Electrically ad in Life, April 25, 1969, 68.

28. Isenstadt (2006); Hales, Outside the Gates of Eden: The Dream of America from Hiroshima to Now (Chicago: University of Chicago Press, 2014), 109.

29. Colomina, Domesticity at War (Barcelona: Actar, 2006), 283; Frank Trippett, "The Great American Cooling Machine," Time, August 13, 1979, 75.

30. Archer $(2005,258)$.

31. Pimlott, Without and Within: Essays on Territory and the Interior (Rotterdam: Episode, 2007), 243. Data on current suburban population are from Lawrence A. Herzog, Global Suburbs: Urban Sprawl from the Rio Grande to Rio de Janeiro (New York: Routledge, 2015), 1. Data on the spread of air conditioning in US households are from Biddle $(2008,42)$ and Energy Information Administration, US Department of Energy, "Air Conditioning in Nearly 100 Million U.S. Homes," August 19, 2011. "http://www/"http://www.eia.gov/consumption/residential/reports/2009/air-conditioning.cfm.

32. Biddle, "Explaining the Spread of Residential Air Conditioning, 1955-1980," Explorations in Economic History 45, no. 4 (September 2008): 402, On the extensive use of climate control in southern California and its influence on architecture, see Barbara Flanagan, "The Great California Indoors." Metropolis 21, no. 8 (April 2002): 94-96, 124, 130. On the impact of air conditioning on the growth of southern and Sun Belt cities, see Arsenault, "The End of the Long Hot Summer: The Air Conditioner and Southern Culture" Journal of Southern History 50, no. 4 (November 1984): 597-628 and Abbott, "Urbanizing the Sunbelt," OAH Magazine of History 18, no. 1 (October 2003): $11-16$. 